УДК 378+37.09

DOI https://doi.org/10.24919/2308-4863/34-4-33

Ольга НЕСТЕРОВА,

orcid.org/0000-0002-5952-4664

кандидат педагогічних наук, дочент,

доцент кафедри перекладу

Національного технічного університету «Дніпровська політехніка»

(Дніпро, Україна) olnesterova@yahoo.com

Альвіна ГАВРИЛОВА,

orcid.org/0000-0002-9381-5545

стариий викладач кафедри перекладу

Начіонального технічного університету «Дніпровська політехніка»

(Дніпро, Украӥна) havrylova.a.v@nти.one

\title{
ВИКЛАДАННЯ ІСПАНСЬКОЇ МОВИ В УМОВАХ ДИСТАНЦЙНОГО НАВЧАННЯ ТА СПЕЦИФІКА ПІДТРИМКИ АКАДЕМІЧНОЇ ДОБРОЧЕСНОСТІ ЗДОБУВАЧІВ ОСВІТИ
}

\begin{abstract}
У статті розглядаються питання підтримки академічної доброчесності у зв 'язку зі специфікою викладання дисиипліни «Практичний курс третьої іноземної (іспанської) мови» зі студентами-філологами третього курсу nід час використання платформи Moоdle та засобів Microsoft Office, а також соціальних мереж та программесенджерів. У зв'язку з тим, що проблематика дослідження дистаниійного навчання переважно включає технічні питання, вибір програмного забезпечення, організацію взаємодї педагогів та здобувачів освіти, адаптацію навчального контенту дистаниійного навчання, особливості викладання курсів з іноземних мов в умовах дистаниійного навчання, забезпечення дотримання здобувачів освіти принципів академічної доброчесності поки щцо перебуває на периферії педагогічних досліджень. Метою дослідження є опис специифіки організації викладання курсу іспанської мови для студентів-перекладачів з огляду на необхідність забезпечення здобувачами освіти принщипів академічної доброчесності. В організації роботи здобувачів освіти з метою забезпечення академічної доброчесності було зроблено акцент на індивідуалізацію навчальної діяльності та додаткову методичну підтримку здобувачів освіти на основі послідовності «розуміння-конкретизація-застосування». За результатами організації дистаниійного курсу з дисципліни «Практичний курс третьої іноземної (іспанської) мови» авторами визначено, щь здобувачі освіти порівняно швидко адаптувалися до нової форми навчання та визначили ї̈ суттєві переваги. Акиентовано увагу на низці невирішених питань, щуо створює можливості для вдосконалення розробленого курсу. До частково вирішених проблем належить і питання забезпечення академічної доброчесності. Незважсаючи на вибрану стратегію попередження проявів недоброчесності, спостерігалися спроби списування під час виконання окремих завдань, а також певні проблеми в процесі виконання групових проектів. Можливими шляхами вирішення таких проблем названо посилення виховного компоненту навчального процесу та подальшу роботу з індивідуалізачії навчання, підвищення рівня мотивації здобувачів освіти.
\end{abstract}

Ключові слова: академічна доброчесність, дистаниійна освіта, викладання іспанської мови, індивідуалізація навчальної діяльності. 


\author{
Olha NESTEROVA, \\ orcid.org/0000-0002-5952-4664 \\ Candidate of Pedagogical Sciences, Associate Professor, \\ Associate Professor at the Department of Translation \\ National Technical University Dnipro Polytechnic \\ (Dnipro,Ukraine),olnesterova@yahoo.com
}

\author{
Alvina HAVRYLOVA, \\ orcid.org/0000-0002-9381-5545 \\ Senior Lecturer at the Department of Translation \\ National Technical University Dnipro Polytechnic \\ (Dnipro,Ukraine), havrylova.a.v@nmu.one
}

\title{
TEACHING THE SPANISH LANGUAGE IN THE CONDITIONS OF DISTANCE LEARNING AND THE SPECIFICS OF ACADEMIC INTEGRITY SUPPORT OF STUDENTS
}

The paper deals with the issues of maintaining academic integrity in connection with the specifics of teaching the discipline "Practical course of a third foreign (Spanish) language" with third-year philology students using the Moodle platform and Microsoft Office, as well as social networks and messenger programs. Due to the fact that the study of distance learning mainly includes technical issues, choice of software, organization of interaction between teachers and students, adaptation of distance learning content, features of teaching foreign languages in distance learning, ensuring compliance with the principles of education, and academic integrity is still on the periphery of pedagogical research, the purpose of the study is to describe the specifics of the organization of Spanish language teaching for students-translators with respect to the need to provide students with the principles of academic integrity. In organizing the work of students in order to ensure academic integrity, emphasis was put on the individualization of educational activities and additional methodological support for students on the basis of the sequence "understanding-specification-application". According to the results of the organization of a distance course in the discipline "Practical course of the third foreign (Spanish) language" the authors determined that students relatively quickly adapted to the new form of education and identified its significant advantages. Emphasis is put on a number of unresolved issues, which creates opportunities for improving the developed course. The issue of ensuring academic integrity is one of the partially solved problems. Despite the chosen strategy of prevention of manifestations of dishonesty, there were attempts to cheat when performing certain tasks, as well as certain problems in the process of group projects. Possible ways to solve such problems are strengthening the educational component of the educational process and further work on the individualization of education, increasing the level of students' motivation.

Key words: academic integrity, distance education, teaching Spanish, individualization of educational activity.

Постановка проблеми. Умови функціонування сучасного суспільства та системи освіти визначаються, зокрема, зростанням інформаційного простору та взаємодією світових культур. Тому для освітян стають важливими знання і навички у сфері виховання та освіти молодого покоління українців, як освічених громадян країни, що вміють швидко адаптуватися до комунікації та співпраці з різними представниками різних націй світу. Реформа освіти передбачає розвиток інформаційних та віртуально-комунікаційних технологій, які навчать здобувача освіти орієнтуватися в просторі знань та отримувати необхідні знання протягом життя.

За останні роки відбулося помітне скорочення аудиторного часу на засвоєння матеріалу, багато уваги приділяється самостійній роботі. Можемо стверджувати, що постає нова форма навчання, яка орієнтована на індивідуалізацію та диференціацію навчального процесу, використовує інтернет-технології та має високу ефективність у реалізації освітніх програм. Слід також зазначити, що умови пандемії дали потужний поштовх розвитку дистанційної форми навчання у всьому світі. Однак набутий досвід практичного застосування дистанційного навчання вимагає глибокого осмислення, вироблення вимог, характеристик, певних підходів до вирішення нагальних проблем, кількість та складність яких досить значна.

Перше з важливих завдань дистанційної освіти $\epsilon$ поєднання переваг традиційної та онлайн-освіти для успішного впорядкування освітнього процесу кожного здобувача освіти, тобто створення умов для підвищення рівня індивідуалізації навчання. Тобто необхідно вибудувати стратегію викладання та самостійної роботи таким чином, щоб здобувачі освіти мали можливість розвивати свої знання, вміння та навички відповідно до власних можливостей. Такий підхід стає винятково важливим у системі вищої освіти, де важливо також 
забезпечити врахування уподобань та стратегій розвитку кар'єри студентів, особливо старших курсів, не втрачаючи при цьому показників якості (Ус, Манькута, 2014).

Під час навчання іноземних мов, звичайно, особисте спілкування викладача та студента, студентів між собою $є$ важливим інструментом розвитку навичок спілкування. Тому за необхідності організувати дистанційне навчання мов постає нагальна потреба компенсації відсутності такої інтеракції. Відповідно, постає ряд організаційних проблем, які необхідно вирішувати для підвищення ефективності навчання.

Аналіз досліджень. Питання дистанційної освіти часто розглядаються науковцями та педагогами-практиками різних країн світу, останнім часом - у зв'язку зі стрімким переходом на дистанційне навчання (Блощинський, 2015; Гаврілова, Катасонова, 2017; Носкова, Сардига, 2019). До аспектів дистанційного навчання, які переважно стають об'єктами наукового осмислення, слід насамперед віднести такі аспекти: технічні питання, вибір програмного забезпечення, організація взаємодії педагогів та здобувачів освіти; адаптація навчального контенту до специфіки дистанційного навчання; забезпечення дотримання здобувачами освіти принципів академічної доброчесності; особливості викладання курсів 3 іноземних мов в умовах дистанційного навчання. Проте питання дотримання академічної доброчесності здобувачів освіти в умовах викладання курсів з іспанської мови не знаходить системного відображення в доробку сучасних науковців.

Проте під час аналізу досліджень зарубіжних колег було виявлено, що це питання досить глибоко розроблялося, зокрема, науковцями США, де іспанська мова викладається і як іноземна, і як рідна (Пентон Геррера, 2018; Центр прикладної лінгвістики, 2013). Питання забезпечення та підтримки академічної доброчесності у викладанні іноземних мов висвітлено в публікаціях (Ланг, 2013; Петрич, 2004; Тейлор, Біцак, 2019). Особливості запобігання академічної нечесності під час викладання іспанської мови як іноземної описано, зокрема, в роботах (Корреа, 2014; Гарман, 2013).

Мета статті - описати специфіку організації викладання курсу іспанської мови для студентівперекладачів 3 огляду на необхідність забезпечення здобувачами освіти принципів академічної доброчесності.

Виклад основного матеріалу. Досвід організації дистанційного навчання та організації дистанційного курсу іспанської мови дозволяе стверджувати, що така форма навчання має ряд переваг та недоліків.
На відміну від традиційної освіти, дистанційне навчання створює більш сприятливі умови для реалізації індивідуального підходу завдяки додатковим можливостям роботи 3 технологіями. Це відбувається за рахунок онлайн-учасників та можливості переглядів записів занять чи прослуховування матеріалів для аудіювання. Для студентів, які не могли бути присутніми на занятті, $\epsilon$ можливість доступу до електронного матеріалу та відеозапису уроку. Існує також можливість приєднуватись у будь-який час до самого уроку та вибирати індивідуальний темп засвоєння.

Так, наприклад, під час відпрацювання тем 3 фонетики $є$ можливість прослуховування не лише матеріалів підручника, а й коментарів викладача щодо вимови. Використання дистанційних технологій, безперечно, потребує підготовки відповідних матеріалів програмного забезпечення та індивідуальних інструкцій. Але за швидкого переходу до дистанційного навчання (карантинні заходи) немає потреби в зміні основного плану роботи та навчального посібника (основного підручника).

Дистанційне навчання, без сумніву, потребує від викладача та студента володіння інтернет-технологіями, а також висуває вимоги до технічного забезпечення учасників навчального процесу, адже постає необхідність використовувати цифрові пристрої з певними технічними можливостями. Не менш важливими є навички цифрової грамотності, які визначаються серед ключових навичок XXI сторіччя (Шуппе, 2017). Як показав досвід організації навчального процесу у весняному семестрі 2019-2020 навчального року, здобувачі освіти, незважаючи на часте використання мобільних пристроїв, комп'ютерної техніки, мають складнощі під час роботи з багатьма видами програмного забезпечення i, що є досить несподіваним, порівняно довго адаптуються до деяких програм, зокрема тих, що дозволяють проводити заняття в синхронному режимі.

Перевагою дистанційного курсу є те, що він може бути основним, але також зручним додатком до основного курсу як доповнення або як підтримка тих здобувачів освіти, які мають складнощі 3 вивченням курсу чи 3 певних причин не відвідали значну кількість занять.

Під час розроблення серії занять 3 дисципліни «Практичний курс третьої іноземної (іспанської) мови» зі студентами третього курсу, необхідність яких постала навесні 2020 року, ми орієнтувалися на можливості платформи Moodle та засоби Microsoft Office, а також переваги соціальних мереж та програм-месенджерів.

Платформа Moodle використовувалася переважно в організації асинхронного навчання та 
ключового джерела навчальної інформації. Можливості Microsoft Office використовувалися в peaлізації синхронного навчання, а саме для проведення практичних занять із предмету. Соціальні мережі та месенджери виконували свою функцію комунікації в разі виникнення технічних складнощів, оперативного інформування здобувачів освіти та як один із засобів організації виконання командних завдань.

На платформі Moodle було розміщено такі ресурси:

- перелік тем, які вивчаються;

- посилання на джерела навчальної інформації;

- посилання на додаткові джерела в мережі

Інтернет, які можна використовувати для опрацювання тем;

- питання для підсумкового контролю;

- ресурси для отримання зворотного зв'язку зі здобувачами освіти;

- посилання на програми, за допомогою яких відбувалися заняття в синхронному режимі.

У додатку Microsoft Office Teams були розміщені такі ресурси:

- посилання на джерела інформації для вивчення теми кожного заняття;

- відеозаписи занять;

- аудіозаписи окремих елементів текстів та вправ, які потребують додаткового самостійного опрацювання;

- навчальні матеріали, які використовувалися на заняттях.

В організації роботи здобувачів освіти з метою забезпечення академічної доброчесності було зроблено акцент на індивідуалізацію навчальної діяльності та додаткову методичну підтримку здобувачів освіти на основі послідовності «розуміння-конкретизація-застосування».

Під час роботи 3 фонетичними труднощами здобувачі освіти спиралися на аудіозаписи вправ із підручників, аутентичні іспаномовні аудіоматеріали та записи, створені викладачем, які містили як самі тексти до опрацювання, так і відповідні коментарі та рекомендації для забезпечення правильної вимови. Контроль вимови відбувався як синхронно на заняттях, так і асинхронно: на основі записаних здобувачами елементів контрольних текстів, які надсилалися особисто викладачеві в особистих розмовах через додаток Microsoft Office Teams та 3 використанням можливостей платформи Moodle. Також за виникнення технічних складностей (переважно низька якість інтернетз'єднання) окремі студенти мали можливість подати на перевірку свої завдання за допомогою програм-месенджерів. Така організація роботи
3 мовним фонетичним матеріалом сприяла глибшому опрацюванню відповідних тем та не обмежувала можливостей самовдосконалення здобувачів освіти. Деякі з них під час опитування зазначили, що надсилали викладачеві тільки другий або третій варіант запису контрольного завдання, що свідчить про досить високий рівень самоконтролю та тренування фонетичного матеріалу.

Засвоєння лексичного та граматичного матеріалу з формуванням відповідних навичок відбувалося на основі виконання вправ з базового підручника та додаткових тренувальних вправ 3 ресурсів для підготовки до складання іспитів визначення володіння іспанською мовою як іноземною. У роботі з такими інтернет-ресурсами здебільшого передбачена можливість самоконтролю з використанням правильних відповідей. Крім того, створюється можливість урізноманітнення завдань з урахуванням особливостей сприйняття навчального матеріалу та стилю навчання здобувача освіти.

На етапі розвитку навичок використання лексичних та граматичних конструкцій використовувалися різноманітні мовні ігри та навчальні матеріали, створені за допомогою ресурсів мережі Інтернет (створення хмар слів (word clouds), гнізд слів та ін.). Таким чином, створювалися додаткові можливості для індивідуалізації процесу навчання.

На завершальному етапі роботи 3 граматичними та лексичними матеріалами застосовувався метод проектів, що виконувалися в невеликих групах. 3 метою забезпечення дотримання академічної доброчесності здобувачам освіти було заздалегідь запропонований розподіл завдань для виконання, а студенти мали можливість після обговорень у групах зголошуватися на певний набір завдань до виконання в межах відповідного спільного проекту.

Для поточного та підсумкового контролю використовувався додаток Microsoft Office Forms. Можливість створювати коментарі до відповідей здобувачів освіти у складанні тестових питань виявилася дуже продуктивною щодо керування самостійним навчанням, адже дозволяе коригувати неправильні відповіді та аналізувати помилки під час використання мовного матеріалу, що стали причиною неправильних відповідей.

Для проведення проміжного тестування було налаштовано опції демонстрації правильних та неправильних відповідей і перегляд коментарів. Під час проведення підсумкового тестування такі опції було відключено з метою запобігання списуванню. Із цією ж метою було обмежено час роботи 3 підсумковим тестом та налаштовано зміну послідовності тестових питань. 
Напередодні виконання підсумкового тесту зі здобувачами освіти було проведено обговорення процесу навчання 3 дисципліни 3 метою визначення основних складнощів та слабких місць створеного фактично нашвикоруч дистанційного курсу та можливостей його вдосконалення, а також виявлення можливих загроз із точки зору забезпечення дотримання принципів академічної доброчесності. Основними проблемами, на які звернули увагу здобувачі освіти, стали такі:

1) складнощі з доступом до мережі Інтернет;

2) проблеми в роботі з деякими додатками;

3) недостатній рівень спілкування.

Серед ключових переваг було названо такі:

1) можливість додатково звертатися до матеріалів заняття (записів);

2) можливість виконувати завдання у зручний час;

3) знайомство 3 новими програмами (для створення хмар слів, малюнків тощо).
Висновки. За результатами організації дистанційного курсу 3 дисципліни «Практичний курс третьої іноземної (іспанської) мови» можемо стверджувати, що здобувачі освіти порівняно швидко адаптувалися до нової форми навчання та визначили іiі суттєві переваги. Проте залишається багато невирішених питань, що створює можливості для вдосконалення розробленого курсу. До частково вирішених проблем належить і питання забезпечення академічної доброчесності. Незважаючи на вибрану стратегію попередження проявів недоброчесності, спостерігалися спроби списування під час виконання окремих завдань, а також певні проблеми в процесі виконання групових проектів. Можливими шляхами вирішення таких проблем вважаємо посилення виховного компоненту навчального процесу та подальшу роботу 3 індивідуалізації навчання, підвищення рівня мотивації здобувачів освіти.

\section{СПИСОК ВИКОРИСТАНИХ ДЖЕРЕЛ}

1. Гаврілова Л., Катасонова Ю. Теоретичні аспекти впровадження дистанційного навчання в Україні. Освітологічний дискурс. 2017. № 1-2 (16-17). С. 168-182.

2. Блощинський I. Г. Сутність та зміст поняття «дистанційне навчання» в зарубіжній та вітчизняній науковій літературі. Вісник Національної академії Державної прикордонної служби України. 2015. Вип. 3. URL: http://nbuv.gov.ua/ UJRN/Vnadps_2015_3_4

3. Носкова М. В., Сардига М. В. Аналіз нормативно-правової бази забезпечення існування дистанційної форми навчання в Україні. Молодий вчений. 2019. № 6 (2). C. 346-351. URL: http://nbuv.gov.ua/UJRN/molv_ $20196 \% 282 \% 29 \quad 39$.

4. Ус Г.О., Манькута Я. М. Дистанційна освіта в системі управління якістю послуг ВНЗ. Вісник Східноєвропейського університету економіки і менеджменту. Серія : Економіка і менеджмент. 2014. № 2. C. 135-145. URL: http://nbuv.gov.ua/UJRN/Vsuem_2014_2_17

5. Шуппе Л. Фахова підготовка бакалаврів романської філології в університетах Іспанії та України: спільне i відмінне. Педагогічні науки: теорія, історія, інноваційні технологіï. 2017. № 1. С. 280-290. URL: http://nbuv.gov.ua/ UJRN/pednauk_2017_1_28

6. Teaching Spanish to native Spanish speakers / Center for Applied Linguistics. Washington, DC, 2013. URL: www.cal.org/sns/index.html

7. Correa M. Leaving the "peer" out of peer-editing: Online translators as a pedagogical tool in the Spanish as a second language classroom. Latin American Journal of Content and Language Integrated Learning. 2014. 7 (1). P. 1-20.

8. Harman R. Literary intertextuality in genre-based pedagogies: Building lexical cohesion in fifth-grade L2 writing. Journal of Second Language Writing. 2013. 22.2. P. 125-140.

9. Lang J. M. Cheating lessons: Learning from academic dishonesty. Cambridge, MA : Harvard University Press, 2013.

10. Petrić B. A pedagogical perspective on plagiarism. NovELTy. 2004. 11.1. P. 4-18.

11. Pentyn Herrera L. J. Spanish language education in the United States: Beginning, present, and future. Hkala, Revista de Lenguaje y Cultura. 2018. 23 (2). P. 319-329.

12. Taylor Z. W., Bicak I. Academic Honesty, Linguistic Dishonesty: Analyzing the Readability and Translation of Academic Integrity and Honesty Policies at U.S. Postsecondary Institutions. Journal of Academic Ethics. 2019. 17. P. 1-15.

\section{REFERENCES}

1. Gavrilova L., Katasonova Yu. Teoretyhni aspekty vprovadzhennya dystancijnogo navchannya v Ukrayini [Theoretical aspects of the introduction of distance learning in Ukraine]. Osvitologichnyj dyskurs, 2017. \#1-2 (16-17). S. 168-182 [in Ukrainian]

2. Bloshhynskyj I. G. Sutnist’ ta zmist ponyattya "dystancijne navchannya" v zarubizhnij ta vitchyznyanij naukovij literaturi [The essence and content of the concept of "distance learning" in foreign and domestic scientific literature.]. Visnyk Nacionalnoyi akademiyi Derzhavnoyi prykordonnoyi sluzhby Ukrayiny. 2015. Vyp. 3. URL: http://nbuv.gov.ua/UJRN/ Vnadps_2015_3_4[in Ukrainian]

3. Noskova M. V., Sardyga M. V. Analiz normaty`vno-pravovoyi bazy zabezpechennya isnuvannya dystancijnoyi formy navchannya v Ukrayini [Analysis of the legal framework for ensuring the existence of distance learning in Ukraine]. Molodyj vchenyj. 2019. \# 6(2). S. 346-351. URL: http://nbuv.gov.ua/UJRN/molv_2019_6\%282\%29_39 [in Ukrainian] 
4. Us G.O., Mankuta Ya. M. Dystancijna osvita v systemi upravlinnya yakistyu poslug VNZ [Distance education in the quality management system of university services]. Visnyk Shidnoyevropejskogo universytetu ekonomiky i menedzhmentu. Seriya : Ekonomika i menedzhment. 2014.\#2. S. 135-145. URL: http://nbuv.gov.ua/UJRN/Vsuem_2014_2_17 [in Ukrainian]

5. Shuppe L. Faxova pidgotovka bakalavriv romanskoyi filologiyi v universytetah Ispaniyi ta Ukrayiny: spilne i vidminne [Professional training of bachelors of Romance philology at universities in Spain and Ukraine: common and different.]. Pedagogichni nauky: teoriya, istoriya, innovacijni tehxnologiyi. 2017. \# 1. S. 280-290. URL: http://nbuv.gov.ua/ UJRN/pednauk_2017_1_28 [in Ukrainian]

6. Teaching ${ }^{-}$Spanish to native Spanish speakers / Center for Applied Linguistics. Washington, DC, 2013. URL: www.cal.org/sns/index.html

7. Correa M. Leaving the "peer" out of peer-editing: Online translators as a pedagogical tool in the Spanish as a second language classroom. Latin American Journal of Content and Language Integrated Learning, 2014. 7(1). P. 1-20.

8. Harman R. Literary intertextuality in genre-based pedagogies: Building lexical cohesion in fifth-grade L2 writing. Journal of Second Language Writing. 2013. 22.2. P. 125-140.

9. Lang J. M. Cheating lessons: Learning from academic dishonesty. Cambridge, MA: Harvard University Press, 2013.

10. Petrić B. A pedagogical perspective on plagiarism. NovELTy. 2004. 11.1. P. 4-18.

11. Pentyn Herrera L. J. Spanish language education in the United States: Beginning, present, and future. Hkala, Revista de Lenguaje y Cultura. 2018. 23(2), P. 319-329.

12. Taylor Z.W., Bicak I. Academic Honesty, Linguistic Dishonesty: Analyzing the Readability and Translation of Academic Integrity and Honesty Policies at U.S. Postsecondary Institutions. Journal of Academic Ethics. 2019. 17. P. 1-15. 